Prof. G. Dunand of the International Labour Organization showed how economic mutual penetration has been practised in Europe on a minor scale for centuries. For such exchanges it was accepted and convenient to use mainly one language, Latin, and later French, and more recently English, and also German in Eustern Europe. The universal use of French or English for European relations has, however been increasingly questioned since language has become an essential element of conscious nationhood and indeed nationalism. Nowadays, supremacy would not readily be granted to the language of any one of the great powers, as, for example, English or Russian. Hence the multiplication, in particular since 1919, of bilingual treaties and multi-lingual international conferences, which have given birth to the profession of conference interpreter and to an extraordinary development of translation for inter. national relations.

From this historical review, Dr. O. G. Pickard, principal of the Ealing Technical College and School of Art posed the question: "Do we then ask the schools to devote less attention to French and take up other languages in its place ?" This has been tried; during the interim period of the two World Wars there was a determined attempt to introduce a great deal of Spanish to English schools for commercial reasons in place of French. The immediate result of this attempt was to antagonize the teachers of French all over Britain, who cloarly saw their vested interest in the teaching of this language threatened by the proposals to introduce Spanish in its place.

So far as the schools are concerned, the question is "whether a third foreign language should find a place in the school curriculum so that it might be possible for school children to learn say, French, German and Russian, or French, Spanish and Swedish, as a normal practice during their school careers. With the growing close association between the economy of Britain and that of Western Europe, it may be necessary to do much more language teaching in schools than has been the practice hitherto [in Britain].
This in turn may lead to a lengthening of the secondary school course as happened on the Continent where it is unusual for the secondary school course for the grammar school stream to finish before 19 or 20 years of age". Neither the schools nor the Ministry of Education have taken kindly to this particular view. The place for teaching the less common languages may be in further education.

Dr. M. B. Brodie of the Administrative Staff College, Henley, and Dr. Walter Goldherg of the Gothenburg Srhool of Business Administration, Sweden, wero both concerned with management development. Brodie stated that businesses which expand and grow more complex in character require relatively more managers. While quantitative estimates must be cautious, since they are likely to transpose present-day notions and assumptions too readily to the future, one estimate which attempts to allow for qualitative changes suggests an increase of about 50 per cent in the number of executives needed over the next ten years.

Throughout Europe, the shortage of staff of calibre for teaching and for research in managment is widespread and serious. Weakness on the staff side cannot but jeopardize the whole quality and character of any programme. "The limitations of educational ventures run with second-rate staff are too manifold to need enumerating."

Dr. Goldberg gave details of important Swedish developments in the field of management education. In 1957, for example, an investigation showed that the relative number of academically trained top-level managers since 1944 had increased from 58.5 to 84.5 per cent in industry, and from 43 to 54.5 per cent in other enterprises. Sweden proposes to increase its intake of students in business schools to 700 in 1970 more than double the 1955 figures of 325 .

All the papers have been brought together in a publication, Continental Comparisons, which can be obtained from the British Association for Commercial and Industrial Education, Publications Department, 26a Buckingham Palace Road, London, S.W.1, price $10 s$.

\title{
PERUVIAN ORCHIDS
}

HE appearance of Part 4 of Charles Schwein-
furth's Orchids of Peru* marks the completion
of actask which has nocessitated continuous and
concentrated research over a period of many years.
At last we now have a comprehensive modern account
of the orchids of an Andine country, a region which
is not only one of the richest in orchids in the world,
but which is the original home of the parents of many
of our finest cultivated orchid hybrids. This excellent
account will not only be of service to students or
visitors wishing to identify Peruvian orchids but will
also facilitate the study of orchids from the neighbour-
ing Andine countries of Bolivia, Ecuador and Colom-
bia which have many species in common with Peru.
This final part contains among others the important
genera Odontoglossum, Miltonia and Oncidium (includ-
ing Cyrtochilum), the last-named being represented by
more than 70 species. Like the three preceding

* Chicago Natural History Museum. Fieldiana: Botany. Vol. 80, No. 4: Orchids of Peru. By Charles Schweinfurth. Pp. v+787-1005. parts, Part 4 is well illustrated, containing thirtythree charming line drawings and one half-tone plate of representatives of all the more important genera, thus bringing the number of illustrations in the whole work to 194. Of special interest are the three pictures of the remarkable alpine genus Telipogon most members of which are found only above $2,000 \mathrm{~m}$. altitude.

Closer examination of the text in all these parts shows, however, how much more collecting is necessary in Peru before a really satisfactory final account of its orchid flore can be prepared. The author has in many casses not seen any specimens of the species dealt with, having had to be satisfied with deseriptions or photographs of the original specimens scattered in various herbaria. Here then is an evident field for future work, since it cannot be doubted that with really good field collections available many of the outstanding problems could be solved and a more complete account given even of those species which are comparatively well known. V. S. SUMMERHAYES 